\title{
Reversibility of radiological appearances during clinical improvement in colonic Crohn's disease
}

\author{
J. HYWEL JONES, J. E. LENNARD-JONES, AND \\ A. C. YOUNG \\ From St Mark's Hospital, London
}

\begin{abstract}
SUMMARY Reversion of radiographic signs has been observed in 11 patients with colonic Crohn's disease during treatment. The commonest radiographic change has been healing of ulcers which are often of a collar-stud type or appear as fissures. Radiographic improvement has been associated with clinical improvement.
\end{abstract}

There have been isolated reports of radiographic reversion to normality in patients with idiopathic proctocolitis (Keeley, Cohel, and Hodes, 1961; Kirsner and Woert, 1964; Marshak and Linder, 1966; Goldberg. Carbone, and Margulis, 1968), but there have been no similar descriptions for Crohn's disease. Crohn and Yarnis (1966) stated that radiographic reversion of the disease process could sometimes be demonstrated in granulomatous colitis, but they gave no details. This paper provides evidence for the reversibility of certain radiographic signs seen in Crohn's disease when it affects the large intestine.

\section{MATERIAL}

In the 11 patients with Crohn's disease who were selected for study all had shown radiological improvement during treatment. The diagnosis of Crohn's disease was made on the basis of the clinical, pathological, and radiological criteria recently reviewed by Lennard-Jones, Lockhart-Mummery, and Morson (1968). All the patients had colonic Crohn's disease and the diagnosis was confirmed by the finding of typical sarcoid granulomata in every patient in biopsy material or surgical specimens. Ten of the patients were treated at St Mark's Hospital and one (case 2) at the Central Middlesex Hospital. The technique usually employed for visualizing the colon was the instant enema (Young, 1963).

Three of the patients are described in detail, and data from the others are summarized in the Table.

CASE 1 A 25-year-old research chemist was admitted to St Mark's Hospital in July 1966 with a five-year history of diarrhoea and weight loss. Sigmoidoscopy revealed patchy ulceration of the mucosa and radiographs showed extensive ulceration throughout the colon (Fig. 1). He was given ACTH beginning with 80 units daily and after a month he felt well and had normal bowel actions. Radiographs showed that ulceration had disappeared and haustral folds returned (Fig. 2).

The patient was discharged taking prednisone and sulphasalazine as a maintenance regime but was readmitted in August 1967 because of a recurrence of diarrhoea and weight loss associated with an anal fistula and abscess. Radiographs showed a return of ulceration in the colon. He received local treatment for the abscess and was given a further course of ACTH which resulted in clinical and radiological improvement though the latter was not as marked as in the previous year. He left hospital continuing on self-administered ACTH injections but was readmitted in September 1968 because of extensive perianal abscesses and fistulae which necessitated colectomy. A preoperative barium enema (Fig. 3) showed definite haustration and slight ulceration.

The mucosa of the excised colon appeared largely intact with a fairly uniform appearance of nodularity and guttering of the surface, but close inspection revealed numerous small ulcers (Fig. 4). Microscopic examination showed ulcers which often penetrated from the lumen into the submucosa and muscle in a collar-stud configuration (Fig. 5) together with deep fissuring, oedema of the submucosa, patchy transmural inflammation, and occasional granulomas.

These microscopic changes were more severe than might have been anticipated from the favourable appearances obtained in the last barium examination and from the gross appearance of the operation specimen.

CASE 2 A 21-year-old domestic bursar was admitted to the Central Middlesex Hospital in June 1968 with a four-month history of diarrhoea, abdominal pain, and weight loss. On admission she was pyrexial, had erythema nodosum, and sigmoidoscopy showed a friable mucosa. A rectal biopsy showed granulomata characteristic of Crohn's disease. Intraluminal filling defects and irregularity of the mucosa were seen throughout the colon on barium enema examination (Fig. 6). A blood culture grew coliform organisms. 


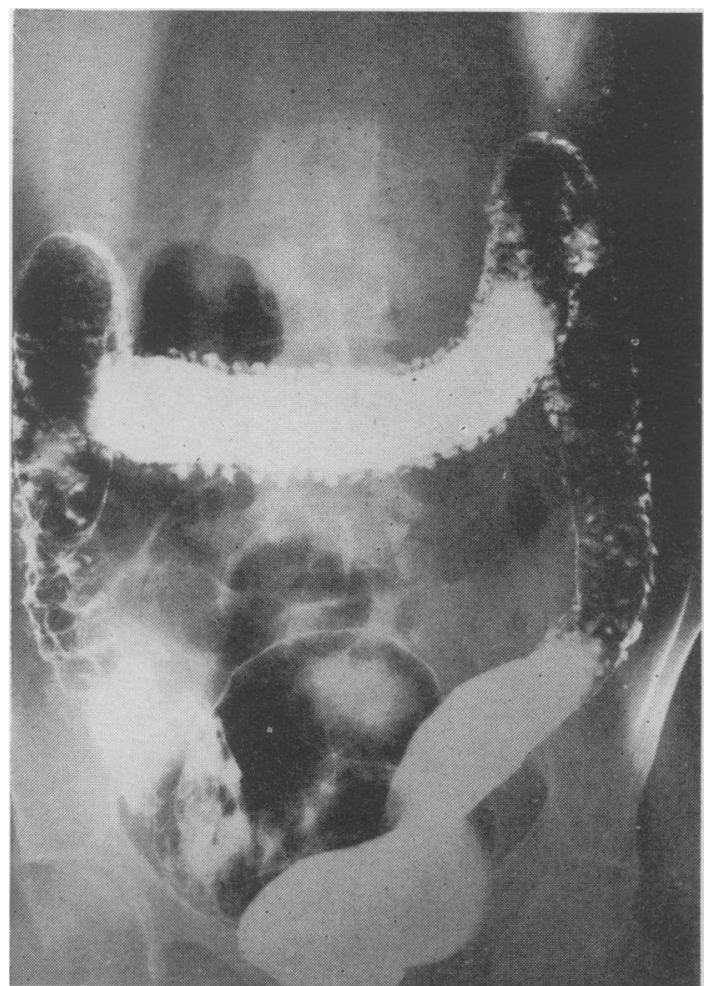

FIG. 1 .

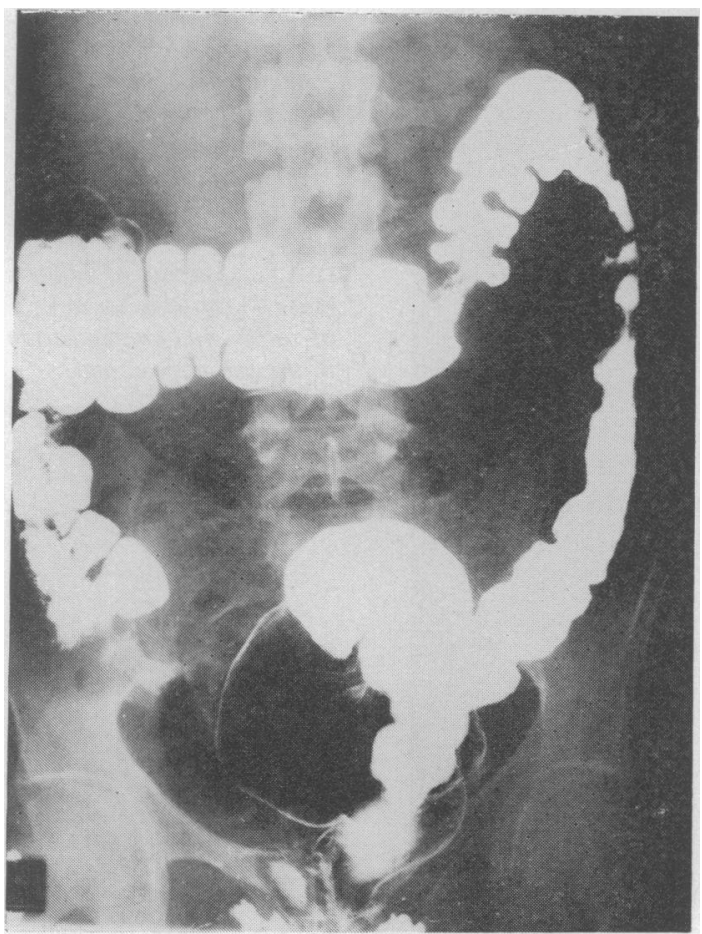

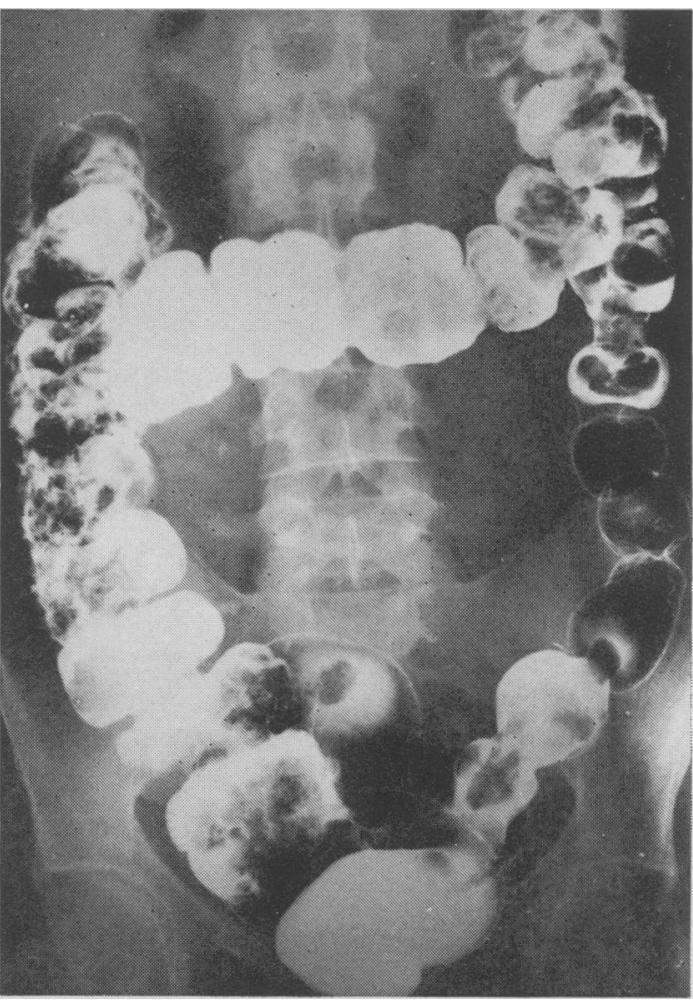

FIG. 2 .

FIG. 1. Initial barium enema (case 1) on 21 July 1966 showing extensive ulceration and loss of haustration.

FIG. 2. Barium enema (case 1) after four weeks' treatment (18 August), showing the disappearance of ulcers and return of haustration.

FIG. 3. Preoperative barium enema from case 1 on 19 November 1968. Only slight ulceration is demonstrated and a well defined haustral pattern is seen in the transverse colon. 

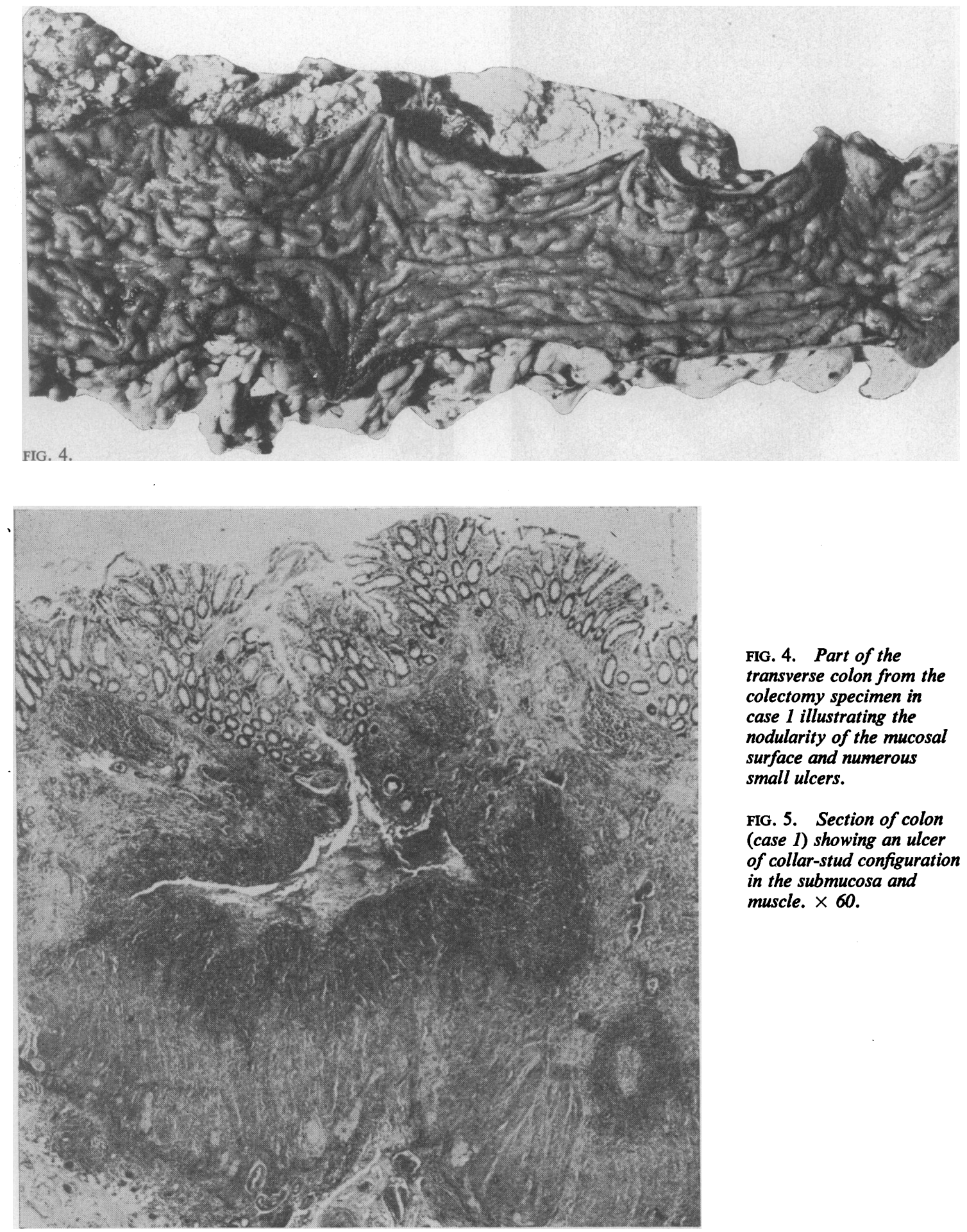

FIG. 4. Part of the transverse colon from the colectomy specimen in case 1 illustrating the nodularity of the mucosal surface and numerous small ulcers.

FIG. 5. Section of colon (case 1) showing an ulcer of collar-stud configuration in the submucosa and muscle. $\times 60$. 

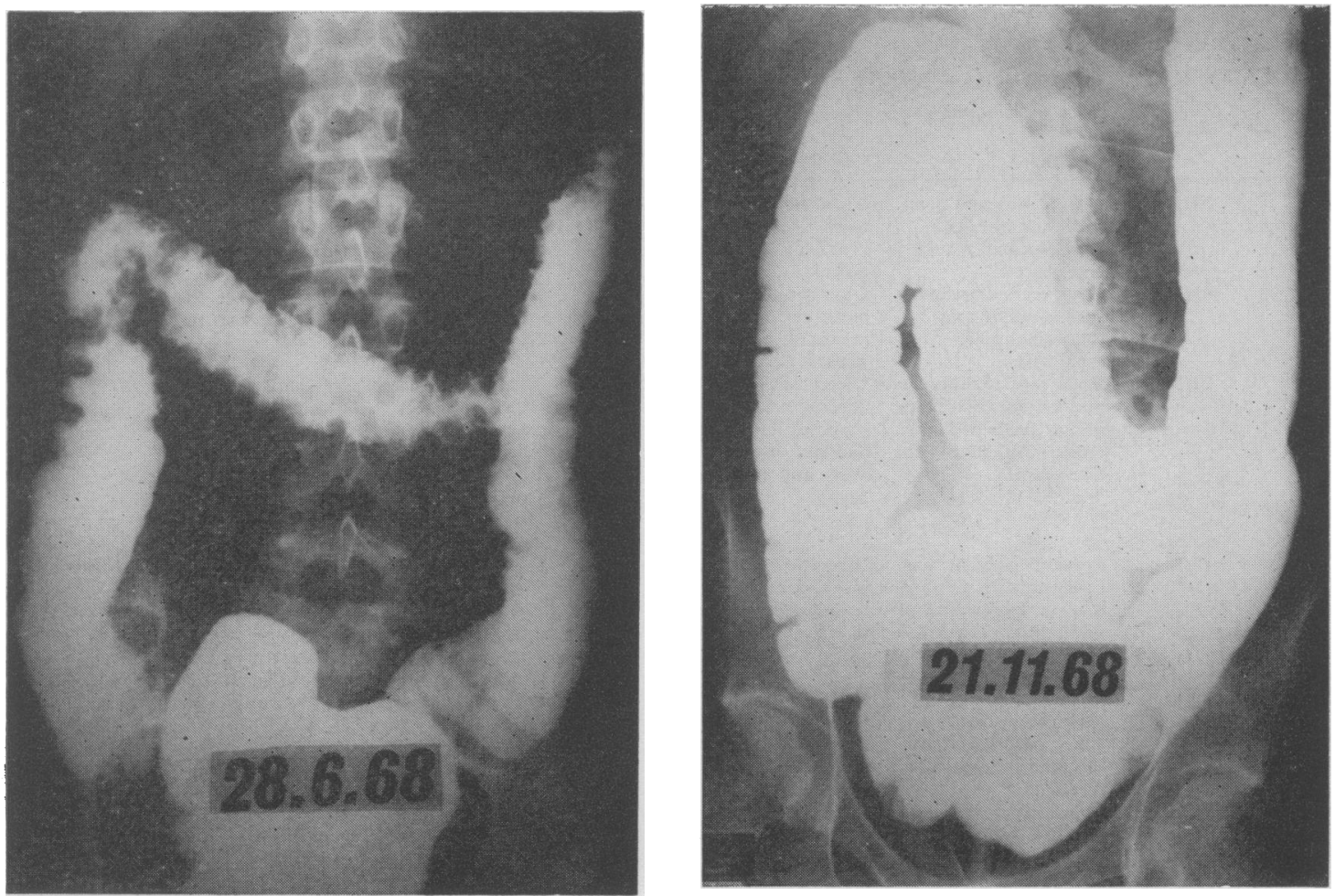

FIG. 6.

FIG. 7.
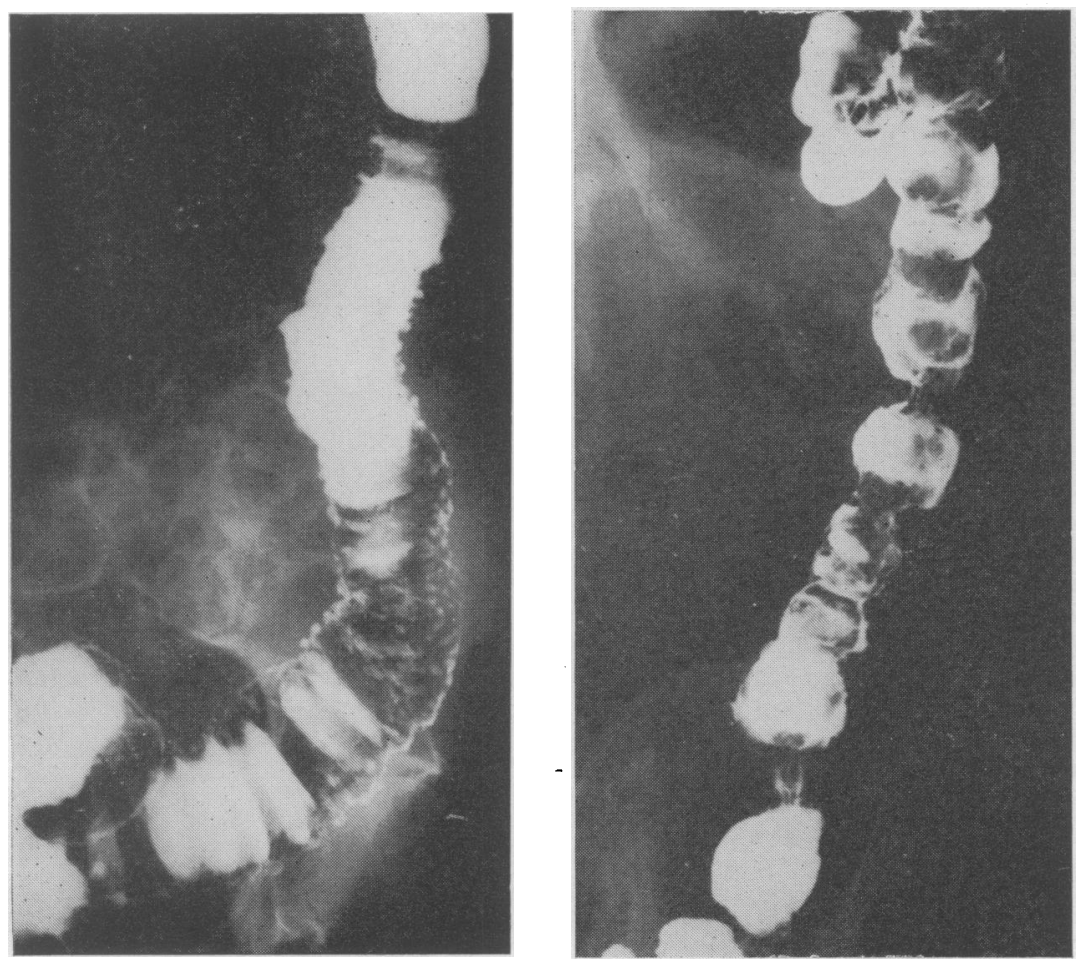

FIG. 6. Initial barium enema (case 2) showing intraluminal projections and mucosal irregularity.

FIG. 7. Barium enema (case 2) after treatment. Filling defects are no longer visible.

FIG. 8. Initial barium enema (case 3) on 20 September 1967 showing ulceration of the left colon.

FIG. 9. Barium enema (case 3) after treatment (13 October 1967). Ulceration has largely disappeared and haustration returned.

FIG. 8.

FIG. 9. 
TABLE

\begin{tabular}{|c|c|c|c|c|c|c|c|}
\hline \multicolumn{2}{|c|}{ RADIOGRAPHIC A } & \multirow{3}{*}{$\begin{array}{l}\text { AND CLINICAL RESPONS } \\
\text { Clinical Features }\end{array}$} & ATMENT & EIG & PATIENTS WITH & \multicolumn{2}{|c|}{ COLONIC CROHN'S DISEASE } \\
\hline \multirow{2}{*}{$\begin{array}{l}\text { Case } \\
\text { Number }\end{array}$} & \multirow[t]{2}{*}{ Age/Sex } & & \multicolumn{3}{|l|}{ Barium Enema } & Change in & Treatment \\
\hline & & & Initial & Interval & Repeat & & \\
\hline 4 & $57 / M$ & $\begin{array}{l}\text { Weight loss and diar- } \\
\text { rhoea for one year } \\
\text { Previous anal fistula } \\
\text { and abscess }\end{array}$ & $\begin{array}{l}\text { Ulceration from rectum } \\
\text { to splenic flexure } \\
\text { Proximal large bowel } \\
\text { normal }\end{array}$ & $5 \mathbf{w k}$ & $\begin{array}{l}\text { Disappearance of } \\
\text { ulcers from left } \\
\text { colon and rectum }\end{array}$ & Remission & $\begin{array}{l}\text { ACTH } \\
\text { Sulphathalidine }\end{array}$ \\
\hline 5 & $41 / F$ & $\begin{array}{l}\text { Four years diarrhoea } \\
\text { with bleeding and } \\
\text { abdominal pain } \\
\text { Anal fistula }\end{array}$ & $\begin{array}{l}\text { Ulceration and loss of } \\
\text { haustration as far } \\
\text { proximally as the } \\
\text { hepatic flexure }\end{array}$ & $5 \mathrm{yr}$ & $\begin{array}{l}\text { Disappearance of } \\
\text { ulcers. Return of } \\
\text { haustration }\end{array}$ & $\begin{array}{l}\text { Remission with } \\
\text { subsequent mild } \\
\text { relapses }\end{array}$ & $\begin{array}{l}\text { Intermittent } \\
\text { prednisone }\end{array}$ \\
\hline 6 & $22 / M$ & $\begin{array}{l}\text { Recurrent anal abscesses } \\
\text { and fistulae, diarrhoea, } \\
\text { and arthritis of knees, } \\
\text { ankles, and elbows for } \\
\text { five years }\end{array}$ & $\begin{array}{l}\text { Ulceration of des- } \\
\text { cending colon and } \\
\text { sigmoid. Asymmetrical } \\
\text { haustration of trans- } \\
\text { verse and ascending } \\
\text { colon }\end{array}$ & 6 wk & $\begin{array}{l}\text { Disappearance of ul- } \\
\text { cers from and } \\
\text { appearance of } \\
\text { haustration in the } \\
\text { descending and sig- } \\
\text { moid colon. More } \\
\text { proximal bowel } \\
\text { loaded with faeces }\end{array}$ & Remission & $\begin{array}{l}\text { ACTH } \\
\text { Surgery to } \\
\text { fistula }\end{array}$ \\
\hline 7 & $18 / F$ & $\begin{array}{l}\text { Previous right hemi- } \\
\text { colectomy for Crohn's } \\
\text { disease. Recurrence of } \\
\text { abdominal pain and } \\
\text { diarrhoea a year ago }\end{array}$ & $\begin{array}{l}\text { Ulceration and loss of } \\
\text { haustration in the } \\
\text { remaining transverse } \\
\text { and left colon. Normal } \\
\text { rectum }\end{array}$ & $15 \mathrm{mth}$ & $\begin{array}{l}\text { Disppearance of } \\
\text { ulcers from des- } \\
\text { cending, sigmoid, and } \\
\text { transverse colon, } \\
\text { reappearance of } \\
\text { haustration }\end{array}$ & $\begin{array}{l}\text { Initial } \\
\text { improvement } \\
\text { but a further } \\
\text { relapse was } \\
\text { treated by left } \\
\text { hemicolectomy. }\end{array}$ & $\begin{array}{l}\text { Prednisone, } \\
\text { sulphathalidine, } \\
\text { later ACTH }\end{array}$ \\
\hline 8 & $65 / M$ & $\begin{array}{l}\text { Diarrhoea and weight } \\
\text { loss for one and a half } \\
\text { years. Nodular anal } \\
\text { canal and ulcers in } \\
\text { rectum }\end{array}$ & $\begin{array}{l}\text { Ulceration and nar- } \\
\text { rowing from the mid- } \\
\text { transverse colon to the } \\
\text { rectum }\end{array}$ & $2 \frac{1}{2} y r$ & $\begin{array}{l}\text { Disappearance of } \\
\text { ulcers and return } \\
\text { of haustration }\end{array}$ & Remission & $\begin{array}{l}\text { Sulphathalidine, } \\
\text { Predsol } \\
\text { suppositories }\end{array}$ \\
\hline 9 & $76 / \mathrm{F}$ & $\begin{array}{l}\text { Intermittent rectal } \\
\text { bleeding and diarrhoea, } \\
\text { treated } 10 \text { years pre- } \\
\text { viously by sigmoid } \\
\text { resection. Past history } \\
\text { of anal fistula }\end{array}$ & $\begin{array}{l}\text { Ulceration in the } \\
\text { descending colon and } \\
\text { narrowing of rectum }\end{array}$ & 3 wk & $\begin{array}{l}\text { Disappearance of } \\
\text { ulcers }\end{array}$ & Remission & $\begin{array}{l}\text { Codeine } \\
\text { phosphate, } \\
\text { bed rest }\end{array}$ \\
\hline 10 & $30 / \mathbf{F}$ & $\begin{array}{l}\text { Six months diarrhoea } \\
\text { with a trace of blood. } \\
\text { Weight loss. Fever } \\
\text { and rebound } \\
\text { tenderness }\end{array}$ & $\begin{array}{l}\text { Scattered ulcers } \\
\text { throughout the colon } \\
\text { with distortion of the } \\
\text { haustral fold pattern }\end{array}$ & 5 wk & $\begin{array}{l}\text { Disappearance of } \\
\text { ulcers and return of } \\
\text { haustration }\end{array}$ & Remission & $\begin{array}{l}\text { Prednisone, } \\
\text { sulphathalidine }\end{array}$ \\
\hline 11 & $49 / \mathrm{M}$ & $\begin{array}{l}\text { Ten years recurrent } \\
\text { anal abscesses and } \\
\text { fistulae with } \\
\text { diarrhoea }\end{array}$ & $\begin{array}{l}\text { Deeply ulcerated sig- } \\
\text { moid colon and nar- } \\
\text { rowed rectum. Normal } \\
\text { proximal large bowel }\end{array}$ & 4 wk & $\begin{array}{l}\text { Disappearance of } \\
\text { ulcers from sigmoid } \\
\text { Persistent narrowing } \\
\text { of rectum }\end{array}$ & Remission & $\begin{array}{l}\text { Prednisone, } \\
\text { steroid } \\
\text { enemas }\end{array}$ \\
\hline
\end{tabular}

Treatment with ampicillin and ACTH produced an immediate clinical improvement. She was then given prednisone and over the next two months became symptom-free with normal sigmoidoscopic appearances. A second barium enema five months after admission, when she was still having prednisone $10 \mathrm{mg}$ daily, showed that the intraluminal projections had disappeared and normal haustrations had returned (Fig. 7).

CASE 3 A 74-year-old grocer was admitted with a twoyear history of diarrhoea. He was febrile and incapacitated by faecal incontinence. Sigmoidoscopy revealed ulceration of the mucosa between 10 to $20 \mathrm{~cm}$ from the anal margin and a rectal biopsy showed appearances typical of Crohn's disease, including sarcoid foci. A barium enema demonstrated ulceration of the whole left colon and rectum (Fig. 8). He was treated with prednisone starting at $\mathbf{4 0 ~ m g ~ d a i l y ~ t o g e t h e r ~ w i t h ~ s u l p h a t h a l i d i n e . ~ A f t e r ~}$ three weeks he was afebrile and had two formed bowel actions daily and no ulcers were visible on sigmoidoscopy. A repeat barium examination showed that the ulceration had largely disappeared and normal haustration had

returned to the distal colon (Fig. 9). He was discharged on a maintenance dose of prednisone and sulphathalidine and has since remained well.

The remaining patients are described in the Table. It will be seen that in each of these eight patients radiological signs of ulceration had disappeared and in five this change was associated with the return of the haustral pattern. The interval between the barium enema examinations varied greatly-from three weeks to five years-but in all cases the radiographic improvement was associated with clinical improvement, a remission being defined as freedom from symptoms with the capacity to lead a full working life.

\section{DISCUSSION}

Analysis of these patients with Crohn's disease in whom radiographic improvement has been observed 
during treatment shows that healing of ulceration is the commonest demonstrable radiographic change. The ulcers often appear as collar-stud projections of barium from the lumen of the colon (Fig. 1) and these may coalesce to produce a line of barium parallel to the lumen. Other authors have observed this type of ulcer in ulcerative colitis and in Crohn's disease (Stein, Roy, and Finkelstein, 1968; Marshak and Lindner, 1968).

Another common form of ulceration in Crohn's disease is fissuring. Fissures are recognizable radiographically as deep, linear extraluminal projections of barium and pathologically as knife-like intramural ulcers lined by a layer of necrotic inflammatory cells. They are important in differentiating Crohn's disease from proctocolitis and were present on the initial radiographs of three patients in this series (cases 5, 7, and 11) before improvement occurred with treatment.

Large, intraluminal filling defects producing a cobblestone appearance (Fig. 6) are occasionally seen in Crohn's disease. These are probably due to mucosal and submucosal oedema. Only one patient (case 2) showed this radiological sign which had disappeared in a repeat barium examination five months later.

These radiological signs have disappeared and the haustral pattern has reappeared during treatment with a variety of drugs, but nine of the 11 patients were treated with prednisone or ACTH. In one instance (case 6) treatment consisted solely of codeine phosphate and bed rest. The radiographic improvement has coincided with clinical improvement and in one patient (case 1), who subsequently had a relapse, it was possible to demonstrate, during the relapse, any return of the radiographic abnormalities which again disappeared with treatment. The pathological findings in the colon removed at operation in case 1 show that active disease may persist despite a great improvement in radiographic appearances, because the barium enema performed shortly before operation showed an almost normal colon (Fig. 3).

The reversibility of radiographic signs in colonic Crohn's disease suggests that radiographs could provide an objective index of progress when assessing the efficacy of treatment.

We are grateful to Dr F. Avery Jones for his help and permission to publish details of case 2 in this paper. We also wish to thank Dr J. M. Hinton for his clinical assistance and Dr B. C. Morson for his help with the pathology. Mr N. Mackie kindly provided the photographs.

\section{REFERENCES}

Crohn, B. B., and Yarnis, H. (1966). Granulomatous colitis: an attempt at clarification. J. Mt Sinai Hosp., 33, 503-513.

Goldberg H. I., Carbone J. V., and Margulis, A. R. (1968). Roentgenographic reversibility of ulcerative colitis in children treated with steroid enemas. Amer. J. Roentgenol., 103, 365-379.

Keeley, F., Cohel, V. K., and Hodes, P. J. (1961). A roentgenologic remission in ulcerative colitis. Ibid, 86, 906-910.

Kirsner, J. B., and Woert, M. V. (1964). Irreversibility and reversibility in ulcerative colitis. Med. Clin. N. Amer., 48, 143-157.

Lennard-Jones, J. E., Lockhart-Mummery, H. E., and Morson, B. C. (1968). Clinical and pathological differentiation of Crohn's disease and proctocolitis. Gastroenterology, 54, 1162-1170.

Marshak, R. H., and Lindner, A. E. (1966). Ulcerative and granulomatous colit is. J. Mt Sinai Hosp., 33, 444-502. 3, 27-61.

Stein, G. N., Roy, R. H., and Finkelstein, A. K. (1968). Roentgen changes in ulcerative colitis. Ibid., 3, 3-26.

Young, A. C. (1963). The 'instant' barium enema in proctocolitis. Proc. roy. Soc. Med. 56, 491-493. 